\title{
ASSESSING READING DIFFICULTIES
}

A diagnostic and remedial approach

\section{LYNETTE BRADLEY}




\section{Macmillan Education Tests and Assessment Advisory Board}

Professor Jack Wrigley, Deputy Vice Chancellor, University of Reading.

Bridie Raban, Department of Educational Studies, Oxford University.

Dr Conrad Graham, Special Education Adviser. Denis R Vincent, Reader in Education, North East London Polytechnic.

(C) Lynette Bradley 1980

All rights reserved. No part of this publication may be reproduced or transmitted, in any form or by any means, without permission.

First published 1980

Revised edition 1984

Published by MACMILLAN EDUCATION LIMITED

London and Basingstoke

Associated companies and representatives throughout the world 


\section{Contents}

Preface

Rhyming and learning to read and spell

Using the test

Before you start to assess

Diagnostic assessment

Procedure

Check for discrimination

Record sheet

Scoring

Interpreting the results

Remediation

Procedure

Starting with new words and the complete non-starter

Early training in categorising sounds

Identifying the causes of reading problems

Auditory and linguistic factors in learning to read

The cues involved in learning to read and write

The visual strategy

The linguistic factor

Visual and linguistic factors

Auditory factors

Auditory discrimination $\quad 24$

Segmentation

Summary

Appendix I Further research 33

$\begin{array}{ll}\text { The first project } & 33\end{array}$

The second project $\quad 34$

The training study $\quad 36$

Appendix II Norms for the sound categorisation test 38

References $\quad 40$

Further publications $\quad 44$

Summary of test instructions-For ease of reference this is to be found on the inside back cover. 


\section{Preface}

We have always known that it is important to foster the young child's developing language skills. Now we have clear evidence, from research, that word play and rhyming games in the pre-school years have a distinct impact on reading and spelling when the child goes to school. ${ }^{48}$

Over 400 young children were tested on their ability to hear rhyme and alliteration in spoken words (Test 2). None of the children had learned to read. When their reading skills were tested three years later, those who had scored well on the word sound test could read and spell significantly better than those who had scored poorly. Children who scored poorly on this test who were then trained in sound recognition, made remarkable progress in spelling as well as in reading.

It is difficult to discover why a non-reader cannot read using conventional reading tests. This research shows that skill at sound categorisation is important for reading and spelling and can be tested in the non-reader. Test 1 , identifies young children and backward readers or non-readers of any age who need special help with sound categorisation. Test 2, can be used with older backward readers. Both tests can be used with children or adults who cannot read or who cannot spell, to identify problems with sound categorisation.

The methods that were used so successfully in the training study were originally developed in successful remedial work with children with severe reading and spelling problems. These methods are outlined in the 'Remediation' section. Sound Pictures, the training package, was developed to help pre-readers master sound categorisation skills before they meet words in print.

This revised edition attempts not only to provide new and additional information, but also to make the test more accessible to the practising classroom teacher. Instructions for using the test have been explained and clarified, and there is a new summary of instructions for daily, routine use.

Oxford, January, 1984 